\title{
Effects of Timber Harvest on Amphibian Populations: Understanding Mechanisms from Forest Experiments
}

RAYMOND D. SEMLITSCH, BRIAN D. TODD, SEAN M. BLOMQUIST, ARAM J. K. CALHOUN, J. WHITFIELD GIBBONS, JAMES P. GIBBS, GABRIELLE J. GRAETER, ELIZABETH B. HARPER, DANIEL J. HOCKING, MALCOLM L. HUNTER JR., DAVID A. PATRICK, TRACY A. G. RITTENHOUSE, AND BETSIE B. ROTHERMEL

\begin{abstract}
Harvesting timber is a common form of land use that has the potential to cause declines in amphibian populations. It is essential to understand the behavior and fate of individuals and the resulting consequences for vital rates (birth, death, immigration, emigration) under different forest management conditions. We report on experimental studies conducted in three regions of the United States to identify mechanisms of responses by pond-breeding amphibians to timber harvest treatments. Our studies demonstrate that life stages related to oviposition and larval performance in the aquatic stage are sometimes affected positively by clearcutting, whereas effects on juvenile and adult terrestrial stages are mostly negative. Partial harvest treatments produced both positive and weaker negative responses than clearcut treatments. Mitigating the detrimental effects of canopy removal, higher surface temperature, and loss of soil-litter moisture in terrestrial habitats surrounding breeding ponds is critical to maintaining viable amphibian populations in managed forested landscapes.
\end{abstract}

Keywords: amphibian, clearcut, forest management, land use, vital rate

$\mathbf{T}$ he extraction of natural resources, such as timber, is strongly associated with the loss and modification of forested habitat in most regions of the world (Putz et al. 2008). Deforestation may be long term (e.g., DeFries 2002, Biggs et al. 2008, Putz et al. 2008) or part of a sustainable forest management system (e.g., Hunter 1999). There is general agreement that timber harvest in temperate regions can have numerous negative effects on species richness and abundance of forest-dependent species, including amphibians (e.g., Bury 1983, Petranka et al. 1994, deMaynadier and Hunter 1995, Grialou et al. 2000, Ross et al. 2000, DeGraaf and Yamasaki 2002, Knapp et al. 2003). Yet, few data exist for species with differing life histories (Ross et al. 2000), and there are conflicting views concerning the mechanisms of population decline across regions, especially among lungless woodland salamanders (e.g., Ash and Bruce 1994, Ash 1997, Petranka 1999). This lack of data is of great concern because recent estimates indicate that 1896 species of amphibians worldwide, about one-third, are currently threatened with extinction (Stuart et al. 2004), and 89\% of all threatened species are affected by habitat loss (Young et al. 2004). Despite recognition of habitat loss and alteration as major contributors to amphibian declines, the effects of structural habitat change have not been well studied for amphibians (Gardner et al. 2007, deMaynadier and Houlahan 2008).

We initiated a collaborative research project with a primary goal of understanding the mechanisms by which timber harvest affects pond-breeding amphibian populations. Although past studies of timber harvest effects have focused on species richness or abundance or both (reviewed in deMaynadier and Hunter 1995, Gardner et al. 2007), we believe that the response of individual amphibians to timber harvest and the subsequent effects on population demography are critical to understanding the effects of timber harvest on these animals (Armstrong 2005, Todd and Rothermel 2006). Studies of effects on vital rates (birth, death, immigration, emigration) are essential in mitigating population declines or losses. Understanding the mechanisms of decline from timber harvest may also 
yield insights on declines from other types of land use. Specifically, clearcutting is a form of canopy loss that shares several, but certainly not all, features of agricultural, industrial, and urban development. Understanding mechanisms may help land managers to mitigate some of the most detrimental practices to protect particular species of interest.

We focused on amphibians for several reasons. First, because most amphibian species possess a complex life cycle (distinct aquatic larval and terrestrial juvenile-adult phases), the loss or alteration of either aquatic or terrestrial habitats by timber extraction can negatively affect their vital rates. Further, although aquatic habitats are necessary for reproduction, juveniles and adults of most species spend the majority of their lives in terrestrial environments (Semlitsch 1998, Semlitsch and Bodie 2003). They possess small home ranges and have relatively limited dispersal capacity, compared with mammals or birds. Also, limited physiological mechanisms to prevent water loss necessitate the use of relatively cool, moist forested habitats, in conjunction with the use of underground refuges or coarse woody debris (CWD) to maintain high moisture levels. Thus, we assume that removal of the forest canopy or CWD would expose amphibians to warmer and drier microclimate conditions (Ash 1995, Harpole and Haas 1999) that could eventually lead to lower survival (Todd and Rothermel 2006) or higher evacuation of habitats (Semlitsch et al. 2008). Thus, amphibians can be useful bioindicators of environmental change because they are sensitive to habitat alteration associated with timber extraction (Welsh and Droege 2001), they play a major role in forest food webs as both predators of invertebrates and prey of larger vertebrates (Davic and Welsh 2004), and they make up a significant portion of animal biomass available to other trophic levels (Gibbons et al. 2006, Peterman et al. 2008).

In this article, we summarize our published results on the effects of timber harvest treatments on pond-breeding amphibian populations during the first four years following experimental harvests. Our synthesis includes comparisons of (a) forest management treatments, (b) three regions of the United States, (c) nine species, (d) life history stages, and (e) multiple response variables affecting both behavioral and demographic traits. Our approach to understanding timber harvest effects was a collaborative effort that allowed simultaneous and standardized experimental studies across regions to generate results that were comparable and had strong management implications for pond-breeding amphibians.

\section{Experimental and regional approaches}

Although it is unlikely that we can assign precise differences to given factors, identifying similarities in responses across such a wide region would produce robust implications for forest management. Previous studies conducted in different regions and years and on various species demonstrate that responses, especially abundance, differ greatly but are often confounded with many other factors, thereby introducing ambiguity in understanding declines. We selected widely separated sites in Maine, Missouri, and South Carolina to incorporate large differences in climate, amphibian species diversity, forest type, and topography (figure 1).

In the New England Province physiographic region, arrays were located in the Dwight B. Demeritt Forest and the Penobscot Experimental Forest near Orono, Maine. These study sites consisted of mature (at least 60 years old) mixed-deciduous and coniferous stands (Patrick et al. 2006). We established each of the arrays around a central breeding pond that was approximately 10 meters $(\mathrm{m})$ in diameter $\left(\right.$ area $\left.80 \mathrm{~m}^{2}\right)$ and 0.5 to $0.75 \mathrm{~m}$ deep, and constructed by mechanically enlarging existing pools from December 2003 to March 2004. Species used for experimental studies included the spotted salamander (Ambystoma maculatum), northern leopard frog (Rana pipiens), and wood frog (Rana sylvatica).

On the upper Ozark Plateau physiographic region, we located arrays within the Daniel Boone Conservation Area (1424.5 hectares [ha]) in Warren County, Missouri. We situated arrays in mature (80 to 100 years old) second-growth oak (Quercus spp.) and hickory (Carya spp.) overstory, with varying amounts of sugar maple (Acer saccharum) in the understory (Semlitsch et al. 2008). Each array was centered on a small breeding pond (high-water area 160 to $330 \mathrm{~m}^{2}$ ). These ponds, originally built for other wildlife, are between 27 and 47 years old and have naturally colonized breeding populations of up to 14 species of amphibians (Hocking et al. 2008). Species used for experimental studies included the spotted salamander, American toad (Bufo americanus), gray treefrog (Hyla versicolor), and wood frog.

In the upper Coastal Plain physiographic region of the southeastern United States, we located arrays on the US Department of Energy's Savannah River Site in Barnwell County, South Carolina. These areas are second-growth forests composed predominantly of mature ( $>30$ years old) loblolly pine (Pinus taeda; Rothermel and Luhring 2005). Each array was centered on a natural, isolated, seasonal depression wetland (high-water area 1100 to $1300 \mathrm{~m}^{2}$ ) identified as a "Carolina bay" (Sharitz 2003). Species used for experimental studies included the marbled salamander (Ambystoma opacum), mole salamander (Ambystoma talpoideum), and southern toad (Bufo terrestris).

We established four replicate experimental forest arrays in each region (12 total). Replicates in each region were spaced 0.3 to 3.0 kilometers apart. Each array was centered on an amphibian breeding pond and consisted of a circle of mature forest divided into four quadrants, each containing a different treatment (figure 1). The size of the experimental arrays encompassed $95 \%$ of the estimated core terrestrial habitat needed by breeding populations of six species of salamanders, including species we studied (Semlitsch 1998).

To delineate the treatments around each pond, a circular area with a radius of $164 \mathrm{~m}$ from the pond edge was divided into four equal quadrants (approximately 2.1 ha each in Maine and Missouri; about 4.0 ha in South Carolina; figure 2). In each array, the control treatment (unmanipulated quadrant) was randomly assigned to one quadrant, two clearcut treatments were randomly assigned to the two adjacent quadrants, and 
the partial treatment was fixed to the quadrant opposite the control (figure 2). We designed one clearcut treatment to test the potential for retaining CWD to mitigate the negative effects of clearcutting on amphibians (clearcut retained). Coarse woody debris benefits amphibians by providing moisture-retaining refugia (e.g., Herbeck and Larsen 1999, McKenny et al. 2006). The second clearcut treatment retained little to no CWD (clearcut removed) and was representative of whole-tree harvest, the practice followed in industrial timber management in the southeastern United States, which is analogous to the clearing of forests for agricultural, urban, or industrial development. The partial-cut treatment was designed to simulate regional management that either thinned forests of unmarketable trees (Missouri)
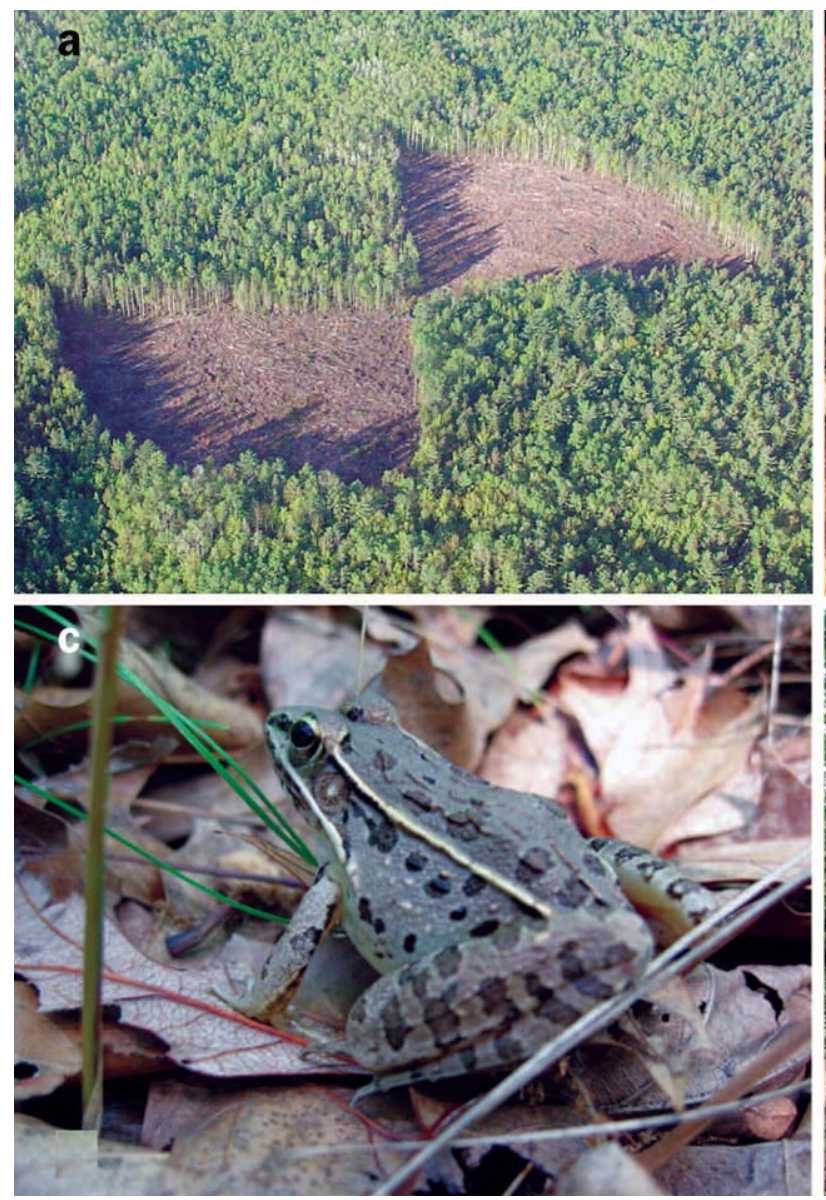

b. Location of field sites

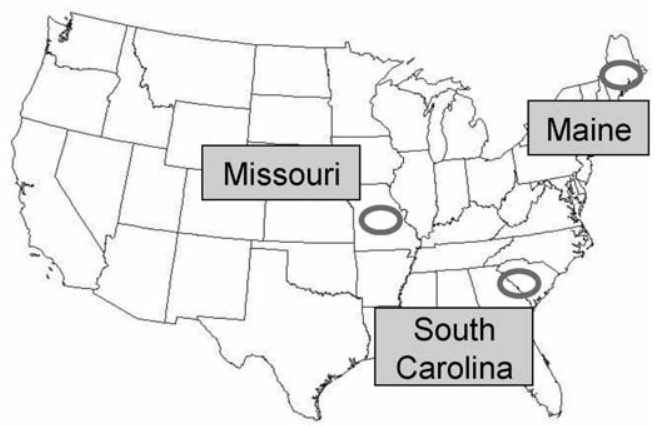

Figure 1. Illustration of (a) the four forest management treatments centered on an amphibian breeding pond and (b) the three LEAP (Land-use Effects on Amphibian Populations) regions. Abbreviation: CWD, coarse woody debris.

or reduced canopy closure by select harvests of some marketable trees (Maine and South Carolina). The partial-cut treatments across all regions resulted in canopy reduction of
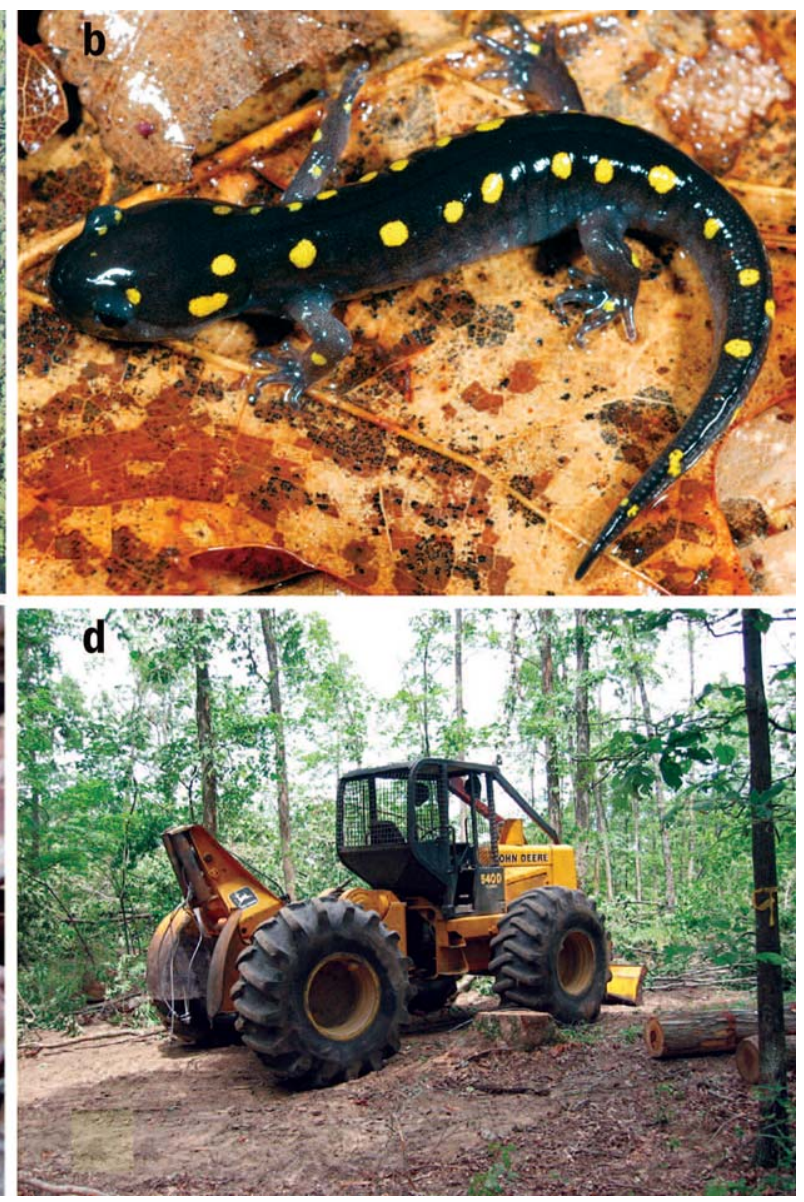

Figure 2. Representative pictures from the Land-use Effects on Amphibian Populations (LEAP). (a) Aerial photograph of the four forest management treatments centered on an amphibian breeding pond in Maine's LEAP Gilman site; (b) a spotted salamander; (c) a leopard frog; and (d) a log skidder used in Missouri. 
about $50 \%$ to $60 \%$. Treatments were applied in Maine from November 2003 to April 2004, in Missouri from March 2004 to January 2005, and in South Carolina from February to March 2004.

A range of experiments was conducted in replicate arrays that included large-scale comparisons among treatment quadrants ( 2 to 4 ha each) using drift fence and pitfall trap captures and radiotelemetry of free-ranging individuals across timescales of seasons and years. Other experiments were conducted across timescales of seasons, weeks, or days and at small scales using terrestrial enclosures $(3 \times 3 \mathrm{~m}$ pen or a cage 15 centimeters in diameter) and aquatic mesocosms (1000-liter cattle tank or 200-liter wading pool) within treatment quadrants.

We included only response variables found to be statistically significant in the source study and those testing two or more of the four timber harvest treatments from our design (see the appendix at http://hdl.handle.net/10355/1365). Although other responses have been tested and some were found to be statistically nonsignificant, our purpose was to highlight those effects that have been shown to clearly contribute to demographic responses in amphibians. To standardize response variables, we calculated relative effect size (percentage) for each variable by subtracting the mean value of each treatment by the mean value of the control, dividing the result by the mean value of the control, and then multiplying by 100 . The resulting value was then assigned a positive or negative sign depending on whether the effect would be expected to have beneficial (i.e., positive) or harmful (i.e., negative) consequences for population growth.

\section{Forest treatment effects on amphibians}

Our studies generated 33 statistically significant effects of timber harvest treatments on a broad range of pond-breeding amphibian responses, some positive and some negative (see the appendix; http://hdl.handle.net/10355/1365). The average net effect of timber harvest treatments relative to the control for all 33 responses was negative (figure 3a, 3b). The partial harvest treatment had the smallest effect size $(-7.2 \%)$, followed by the clearcut-removed $(-18.9 \%)$ and clearcut-retained $(-32.2 \%)$ treatments. If we adjust the overall effect size to determine where negative effects are greatest by removing all positive responses, the partial harvest treatment still has the smallest effect size $(-37.3 \%)$ followed by the clearcut-retained $(-61.8 \%)$ and the clearcut-removed $(-62.4 \%)$ treatments.

When positive and negative effects are examined separately, the positive effects in clearcut treatments were mostly associated with reproductive behavior at experimental breeding ponds or with aquatic larval growth and development (figure 4). For example, gray treefrogs had much greater male calling activity and

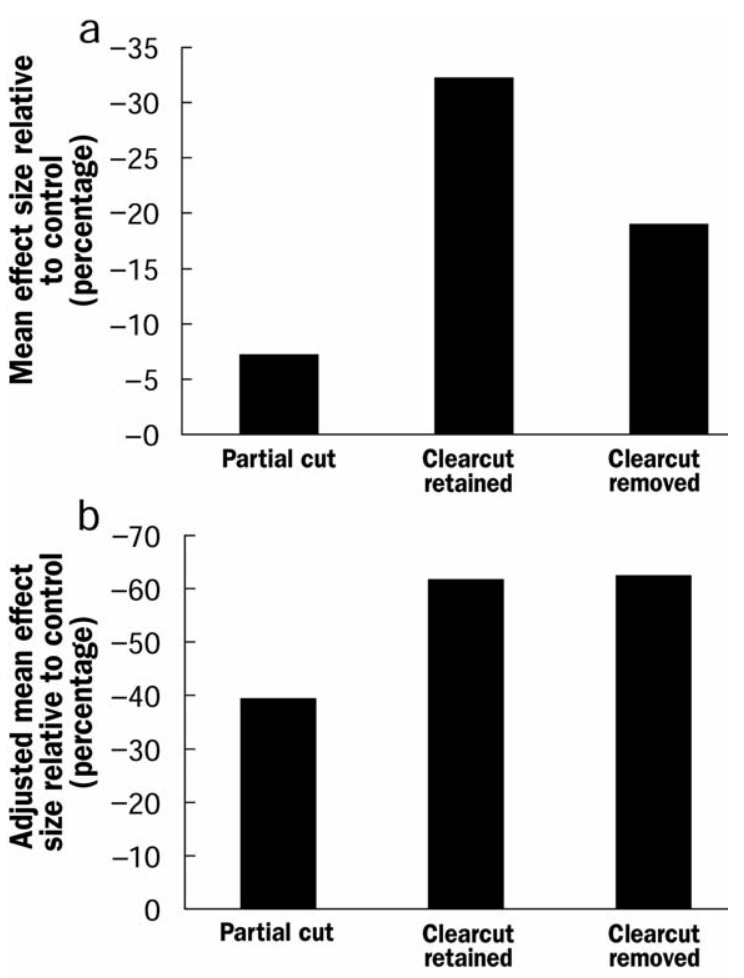

Figure 3. Overview of the (a) mean effect size of all amphibian responses for each forest management treatment relative to the unharvested control, and $(b)$ adjusted mean effect size to determine where the greatest negative effects occur (removing positive effects).
$(-)$

$(+)$

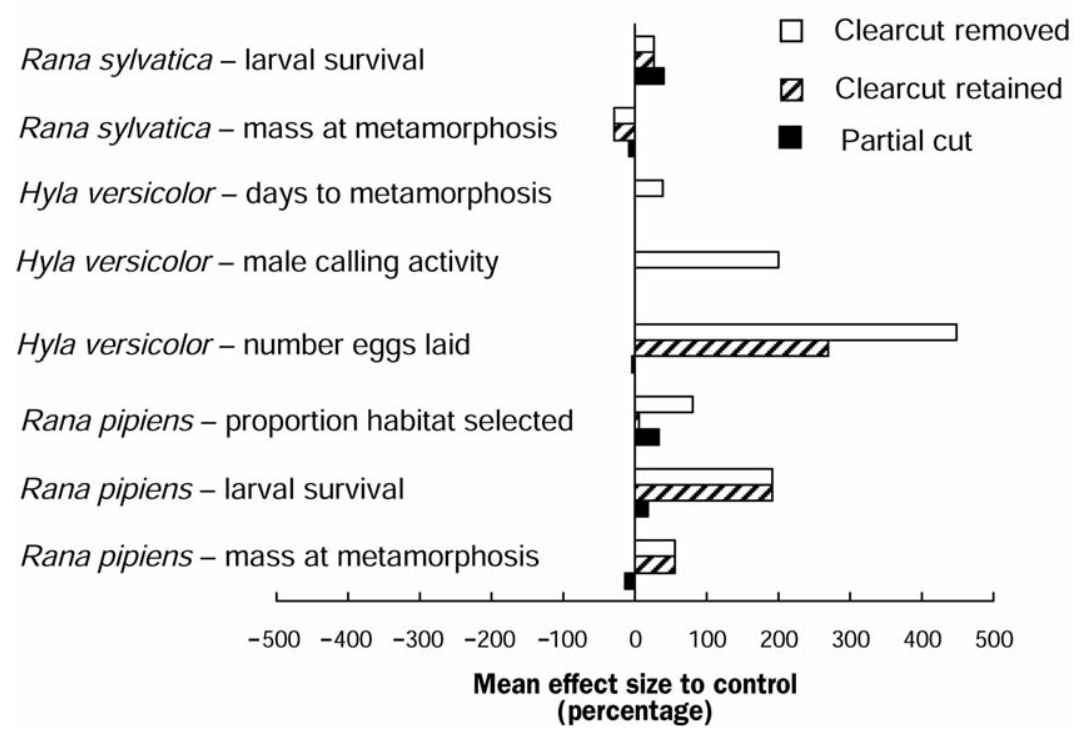

Figure 4. Overview of the mean effect sizes for each larval aquatic or reproductive behavioral response variables (see appendix at http://hdl.handle. net/10355/1365 for the source and details of each response variable). 
oviposition by females in experimental ponds in clearcuts relative to ponds in partial or control forests. Similarly, northern leopard frogs had greater tadpole survival, and gray treefrog tadpoles had faster development, in clearcut experimental ponds relative to ponds in control forests. The exception was the wood frog, which had smaller mass at metamorphosis in all treatments, especially clearcuts, compared with controls (figure 4). Some terrestrial responses $(27 \%, 7$ of 26$)$ were also positive, but only in the partial harvest treatments (figure 5) and never in clearcuts. For example, habitat use and juvenile survival for wood frogs was positive in the partial harvest relative to control treatments. Furthermore, emigration and immigration of southern toads, water loss for mole salamanders, and adult survival for marbled salamanders and spotted salamanders were all positive in the partial harvest relative to control treatments (figure 5). Among the various traits measured, the negative effects of clearcut treatments were most prevalent for behavioral traits (e.g., migration, capture rate, distance moved, relocations) and the vital rate of survival (juvenile and adult), and had the greatest effect $(-112 \%)$ on the physiological trait of water loss (figure 5).

Regional effects appeared to be strongest in South Carolina, with effect sizes increasing sharply between the control and both clearcut treatments, from $-69 \%$ in clearcut-retained to $-127 \%$ in the clearcut-removed treatments. Maine displayed intermediate effects, from $-50 \%$ to $-63 \%$. Missouri showed the smallest effects, from $19 \%$ to $-50 \%$ across treatments, most likely because the gray treefrog was not a primary study species in the other regions, and gray treefrogs displayed significant benefits from using clearcut treatments for reproduction and larval performance. Seven of the nine species we studied displayed similar and negative effects of harvest treatments, especially clearcuts (figure 5).

\section{Ecological consequences and mechanisms}

Our research has demonstrated strong and consistent effects of timber harvest on pond-breeding amphibians across three regions, nine species, and a broad range of physiological, behavioral, and demographic responses. Because of the coordination and standardization of our study, our results allow strong inferences about mechanisms to be made across multiple regions of the eastern United States for many pond-breeding species. Focusing on the mechanisms of decline using experimental approaches at several scales avoids potential problems with detection probability and pseudoreplication
$(+)$

Bufo terrestris - emigration habitat (4th year)

Bufo terrestris - immigration habitat (4th year)

Bufo terrestris - juvenile growth

Bufo terrestris - juvenile survival

Ambystoma talpoideum - emigration

Ambystoma talpoideum - water loss (48 hours)

Ambystoma talpoideum - water loss ( 36 hours)

Ambystoma talpoideum - juvenile survival

Ambystoma opacum - water loss

Ambystoma talpoideum - adult survival

Ambystoma talpoideum - juvenile survival

Rana sylvatica - adult relocations

Rana sylvatica - juvenile pen survival

Bufo americanus - juvenile pen survival

Rana sylvatica - breeding success

Rana sylvatica - habitat selection

Rana sylvatica - body size

Rana sylvatica - juvenile captures

Rana sylvatica - adult captures

Rana pipiens - distance moved

Ambystoma maculatum - juvenile survival (MO)

Ambystoma maculatum - juvenile survival (ME)

Ambystoma maculatum - recapture rate

Ambystoma maculatum - juvenile captures Ambystoma maculatum - adult survival

Ambystoma maculatum - adult captures

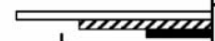

50

100

150

Mean effect size relative to control (percentage)

Figure 5. Overview of the mean effect sizes for each juvenile or adult terrestrial response variable (see appendix at http://hdl.handle.net/10355/1365 for the source and details of each response variable).

that can limit inferences resulting from studies of abundance or occupancy alone (reviewed by Kroll 2009). Further, our results help clarify ambiguities of previous studies by showing that when species are exposed to the same treatments, they differ in their responses to timber harvest—-some species show positive breeding and larval performance while effects on juvenile and adult terrestrial stages of most species were largely negative.

The most consistent negative effects occurred in both of our clearcut treatments, which was not surprising given that clearcutting alters the fundamental structure of forests by removing the canopy and exposing the forest floor to more sunlight and wind, leading to a warmer, drier surface microclimate (Keenan and Kimmins 1993, Chen et al. 1999, Zheng et al.2000), eventually reducing leaf litter (Hughes and Fahey 1994, Ash 1995) and food resources (Seastedt and Crossley 1981). In some regions, clearcutting may also result in soil compaction and disturbance to the soil profile during the course of timber extraction and postharvest site preparations, such as burning. We documented lethal surface soil temperatures at our clearcut sites-more than 40 degrees Celsius $\left({ }^{\circ} \mathrm{C}\right)$ in Missouri (Harper 2007) and more than $43^{\circ} \mathrm{C}$ in South 
Carolina (Todd and Andrews 2008). Lethal temperatures were documented previously in a study of spotted salamanders in New York (Pough et al. 1987). We also showed that such microhabitat conditions lead to rapid water loss and high mortality in small-scale caging studies (Rothermel and Luhring 2005, Rittenhouse et al. 2008, Todd et al. 2008) and most likely provide the direct mechanism for reduced abundance demonstrated in many previous studies.

Behavioral studies show that both juvenile and adult amphibians often avoid entering clearcuts when given a choice (Rittenhouse and Semlitsch 2006, Patrick et al. 2008, Todd et al. 2009; but see Graeter et al. 2008). Using smaller-scale mechanistic studies, we found that retention of CWD helped reduce water loss and increase the survival of juveniles over short periods, especially in slash piles (Rittenhouse et al. 2008). Studying net movement between adjacent control and clearcut treatment quadrants after clearcutting, we also found that CWD retention significantly reduced evacuation of salamanders from clearcuts (Semlitsch et al. 2008). Although this indicates that CWD has a positive short-term effect for amphibians, the two clearcut treatments in Missouri were much more similar to each other in effect size than to the partial treatments, suggesting that leaving CWD for amphibians may increase the probability of successful movement through clearcuts or enhance survival just after metamorphosis, but that does not preclude deleterious effects over the longer term. Moseley and colleagues (2004) found that mole salamanders increased their use of CWD only when there was very little pine litter on the ground, and that salamanders in litter removal treatments had higher activity levels. They concluded that CWD may be important for mole salamanders only immediately after harvesting, when there is little litter or ground cover. More field research is needed to document how species respond to different sizes or decay classes of CWD, determine whether different volumes of retained CWD and species have response thresholds (Ross et al. 2000, McKenny et al. 2006), and determine whether some species, such as the ambystomatid mole salamanders, may be using small-mammal burrows adjacent to CWD instead of using CWD directly (deMaynadier and Houlahan 2008).

We observed movements of amphibians through clearcuts in every region. However, the willingness to travel through clearcuts differed by region and species or stage. In Maine, both juvenile and adult amphibians traveled through clearcuts, and individuals settled for short periods (Patrick et al. 2006, 2008). In Missouri, adults traveled through clearcuts, but virtually no metamorphs traveled successfully through clearcuts. In Missouri, we generally saw more evacuation and avoidance behavior by adults (Rittenhouse and Semlitsch 2006, 2009, Semlitsch et al. 2008). In South Carolina, none of the three species studied showed strong behavioral avoidance of the clearcut quadrants (Graeter et al. 2008): Southern toads preferred clearcuts, southern leopard frogs initially selected clearcuts but ultimately preferred forested treatments, and marbled salamanders selected treatments randomly. Todd and colleagues (2008) found that many adult amphibians (especially toads) migrate through clearcuts but that salamanders tended to avoid them, especially during postbreeding emigration. Overall, we found that long-term use of clearcuts or the inability to evacuate clearcuts resulted in increased mortality in all regions. Thus, strong negative effects of long-term use of clearcuts occurred despite avoidance by some species and despite widely ranging climatic conditions across our three study regions.

Our enclosure survival studies show strong negative effects, but also that the natural heterogeneity of habitats can produce variation in survival rates equal to or greater than those observed in the clearcut treatments in some regions (Harper 2007). In Missouri, for example, we found that juveniles constrained by cages in control quadrants on south-facing slopes with thin soil had lower survival than juveniles constrained in clearcuts on north-facing slopes. Further, radiotelemetry monitoring revealed that temporal variation in habitat quality also affected amphibian habitat choice across large-scale arrays (Patrick et al. 2008), and survival rates (Rittenhouse et al. 2009). In dry years, individuals suffered higher mortality, but they were more likely to use relatively shady and cool sites that were less common and more isolated. Thus, retaining CWD and limiting the amount of timber harvest on high-quality north-slope habitats may provide refuges for amphibians within a landscape that supports timber harvest.

Effects of the partial-harvest treatment were less consistent, but 7 out of 26 responses of juvenile or adult traits were positive (figure 5). The positive effects may have been caused by the enhanced productivity of the herbaceous or shrub vegetation on the forest floor (Zheng et al. 2000). We suggest that the herbaceous-shrub layer may have created a favorable microclimate usually missing from the closed, dense canopy of mature forests, or it may have enhanced the production of invertebrate food resources. In support of this idea, Ross and colleagues (2000) found a strong rise in the percentage of ground cover $(<1$-m high) when tree basal area in Pennsylvania forest stands was reduced. But, they also found that abundance levels of 12 species of salamanders (including four pond-breeding species) dropped at tree basal areas below 15 to $20 \mathrm{~m}^{2}$ per ha (or approximately $50 \%$ to $60 \%$ canopy cover; deMaynadier and Houlahan 2008). Thus, small increases in light levels reaching the forest floor and creating a favorable microclimate may partially ameliorate the negative effects of selectively removing trees. Still, the remaining negative effects of partial-tree harvest were presumably attributable to some of the same changes in microclimate and soil compaction that characterize clearcuts, albeit to a lesser degree. Our results are also consistent with another experimental study done in Virginia showing that three partial harvest treatments also had significantly reduced terrestrial salamander abundance (Harpole and Haas 1999). However, other studies have concluded that partial harvest of timber, including select harvest, has little or no effect on amphibians (e.g., Pough et al. 1987, Grialou et al. 2000, Ross et al. 2000, McKenny et al. 2006). 
We found that timber-harvest effects were consistent across a wide range of demographic and behavioral variables measured across all three regions of the United States. Mechanistically, exposure of amphibians to high temperatures and low moisture in the terrestrial environment amplifies water loss, one of the most critical problems facing amphibians (see Jorgensen 1997). The largest effect size we measured in a single treatment was for water loss in the South Carolina clearcut treatment for mole salamanders (Rothermel and Luhring 2005). Summertime air temperatures in South Carolina are higher than in the other regions (Maine and Missouri), and soil moisture may also be substantially reduced during summer months because the extremely sandy, welldrained Coastal Plain soils do not retain moisture between rainfalls. Further, because all the basic needs of amphibians (e.g., food, shelter) usually require movement overland, every aspect of their lives in the terrestrial environment is affected by water loss. Water loss was rapid in clearcut treatments and on ridgetops in forest controls-anywhere there was greater exposure to sunlight or wind-and this led to increased mortality unless individuals burrowed underground, used CWD, or emigrated to moist ravines (e.g., Missouri) or forested wetlands (e.g., Maine). Individuals usually moved during rain events in Missouri or South Carolina, but in Maine, surface moisture appeared less limiting. As a direct result of water loss limiting amphibian activity, growth rate and survival were reduced whenever the terrestrial microhabitat was warm and dry, most dramatically in the clearcuts (Todd and Rothermel 2006) and to a lesser extent in the partial treatment. We would expect the same reductions in survival to occur with other forms of land use (e.g., agriculture, powerline rightsof-way, road-effect zone) that lower the quality of the microclimate for movement, foraging, and growth, as happens with clearcutting (e.g., Semlitsch et al. 2007).

We did find that two of nine species benefited from clearcuts, but only for reproduction and larval development in aquatic habitats within clearcuts. The gray treefrog is probably representative of an early successional or edge species that prefers habitat that is periodically disturbed and has an open canopy, at least for reproduction. During the nonbreeding season and for overwintering, adults clearly prefer forested habitats (Johnson et al. 2007, 2008). We hypothesize that treefrogs select pools in clearcut treatments over forested treatments for mating and oviposition (Hocking and Semlitsch 2007) because they evolved to breed in new ponds created by uprooted trees within forested habitats (Putz 1983, Ulanova 2000), or in new pools created by other disturbances. These uprooted trees leave holes in the ground that fill with water (Ulanova 2000) and are initially free of predators and competitors; they also receive more sunlight, which increases the water temperature and periphyton productivity, to the benefit of herbivorous tadpoles (Skelly et al. 2005). In Maine, northern leopard frogs also benefited from enhanced larval development in clearcuts (Blomquist and Hunter 2009). Thus, we predict that other species requiring early successional or open habitats for reproduction (e.g., chorus frogs, narrow-mouthed toads, spadefoot toads) would benefit from the presence of breeding pools in clearcuts (e.g., use of skidder ruts; Cromer et al. 2002). Hossack and Corn (2007) reported that disturbance created by wildfire can also benefit some pond-breeding amphibians, especially if fire creates or mimics early successional habitats. This does not mean that all stages of these species would benefit from clearcut or early successional habitat. These stage-specific and carryover effects need to be studied more thoroughly. In some cases we know that adults of species such as the gray treefrog require forested habitat at other times, and will not venture far into clearcuts $(<50 \mathrm{~m}$; Hocking and Semlitsch 2007). Thus, the larval aquatic stage presumably benefits from the presence of pools in small clearcuts, but juvenile and adult treefrogs must find suitable forested habitat nearby (Johnson et al. 2007, 2008). Hossack and Corn (2007) found that toads (Bufo boreas) increased the use of wetlands up to two to three years after wildfires, and suggested that this species was adapted to disturbance created by fire. However, some species, such as the wood frog in Maine, benefited little from breeding pools in clearcuts; these most likely represent species with a strongly forest-dependent life history (Blomquist and Hunter 2009). Knowing the life history requirements of species at all stages is therefore critical for predicting timber-harvest effects or disturbance effects in general. Finally, it is important to note that the presumed benefits of clearcutting to early life stages may not enhance population persistence if timber harvest causes a reduction in postmetamorphic survival (Biek et al. 2002, Taylor et al. 2006, Harper et al. 2008).

Although our study did not differentiate among all possible mechanisms of decline in abundance after harvest, we have strong support for two hypotheses explaining declines. The mortality hypothesis assumes that abundance in clearcuts declines as a result of mortality from lack of refuge or food, from desiccation, and from an inability to evacuate. We found that a large portion of the population dies if they stay in clearcut areas, especially small juveniles (Rothermel and Luhring 2005, Todd and Rothermel 2006, Harper 2007, Patrick et al. 2008, Todd et al. 2008). The evacuation hypothesis assumes that individuals leave clearcuts in response to increasing temperature and reduced moisture and food, and select more suitable habitat in nearby forests. We have found that a portion of the breeding population in Missouri evacuates from clearcuts into neighboring forest habitats, especially adult spotted and ringed (Ambystoma annulatum) salamanders (8.7\% to $35.0 \%$; Semlitsch et al. 2008).

A third hypothesis, the retreat hypothesis, assumes that individuals remain in the clearcuts but move to more suitable underground habitat where individuals survive for limited periods on minimal resources and energy stores, reduce activity, and reemerge as forest succession proceeds. We did not find out in our study, however, whether any of the individuals remaining in clearcut plots retreated underground for some period, as hypothesized for the more fossorial species of woodland salamanders (genus Plethodon; Petranka et al. 
1994), nor do we know the long-term fate of individuals that evacuate clearcuts (Reichenbach and Sattler 2007).

\section{Implications for amphibian conservation and timber harvest}

One goal of this synthesis is to articulate some generalities about timber harvest effects on pond-breeding amphibians, specifically, mechanisms that could result in population decline. Current evidence indicates that the negative effects of clearcutting are pervasive and more or less consistent across regions as diverse as the northeastern, midwestern, and southeastern United States. Clearcutting is directly implicated in the loss of suitable habitat and in the reduction of population size through mechanisms such as reduced terrestrial survival or evacuation by resident amphibians. Consequently, we propose that these effects may extend through much of eastern North America. Moreover, because studies in other regions of North America that address the effects of forest loss on amphibians have demonstrated declines in abundance and richness (e.g., Dupuis et al. 1995, Adams and Bury 2002, Karraker and Welsh 2006, Olson et al. 2007; but see Kroll 2009), it is likely that our research on mechanisms are more broadly applicable to other regions and species not explicitly included in our experiments.

We encourage forest management that enhances the conservation of sensitive species and has a goal of long-term sustainability. Habitat management guidelines for amphibians are available and can be incorporated into harvest operations (Calhoun and deMaynadier 2004, deMaynadier and Houlahan 2008, PARC [www.parcplace.org/habitat management_guide.html]). In general, harvest operations should consider zones of protection around breeding ponds and the adjacent upland habitats to conserve local populations and enhance connectivity at the landscape level (deMaynadier and Houlahan 2008). Clearcutting or timber harvests that remove more than $40 \%$ to $50 \%$ of the canopy should be minimized or eliminated in areas in which amphibian diversity or abundance is known to be high, or in which sensitive species of conservation concern are known to occur (e.g., in the southeastern United States, flatwoods salamander, Ambystoma cingulatum). Additionally, the locations of timber removal should consider topographical features known to promote amphibian persistence (e.g., ravines, north-facing slopes, and uplands within a radius of $150 \mathrm{~m}$ from breeding ponds; Semlitsch and Bodie 2003).

The size of clearcut plots is also important. Our clearcut treatment sites were relatively small (approximately 2.1 ha each in Maine and Missouri, and approximately 4.0 ha in South Carolina), but even at this size it was not certain whether all individuals, especially juveniles, could readily escape to adjacent forests. McKenny and colleagues (2006) found little reduction in abundance of terrestrial Plethodon salamanders in treatments using small $(0.05 \mathrm{ha})$ group harvests. However, Renken and colleagues (2004) found significant reductions in the abundance of several species of amphibians within 5ha clearcut plots in the Ozark hills of Missouri. It is realistic to assume that clearcuts larger than 2 to 4 ha and representative of industrial timber management in the southeastern United States or boreal Canada would have stronger negative effects on amphibian abundance and longer recovery times for populations. It has also been noted that small clearcuts surrounded by large areas of high-quality habitat rather than lowquality habitat (habitat with human development, agriculture, grazing, or high road density, e.g.) allow better connectivity to source habitats, minimize nest parasites and edge predators, and promote diversity of birds (Faaborg 2002). We agree that landscape composition is critical when considering timber-harvest options for amphibians, primarily to ensure complementation of aquatic breeding and adult terrestrial habitats, connectivity to source habitats essential for recolonization, and suitable forested habitat for evacuation from clearcuts (Semlitsch et al. 2008).

On the basis of our findings for the partial treatment, and those of others using selection-harvest methods (summarized by deMaynadier and Houlahan 2008), removal of a portion of the canopy ( $50 \%$ or less) appears to minimize negative effects on amphibian populations. Also, because many trees remain in selection-harvest plots, it is likely that microclimates recover more quickly than in large clearcuts, and thereby longer-term effects are minimized (Ash 1997). However, we acknowledge that more total area is disturbed (by roads and skidder trails) when using selection-harvest relative to the same amount of timber extracted from a clearcut. This results in a potential trade-off between small, intense disturbances versus large, diffuse disturbances. Further, because the effects of partial harvest treatments in our study were more similar to those in the control treatment than to the clearcut treatments, some species that benefit from some open canopy or early-successional habitat for reproduction may be reduced or excluded (e.g., chorus frogs, toads). These early-successional species would most likely benefit from more group-selection cuts that open small patches of forest (Skelly et al. 2005) while avoiding some of the negative effects of larger clearcuts. It also appears that partially thinned forests support a greater abundance of small snakes than do unharvested control forests or clearcuts (Todd and Andrews 2008), reinforcing the benefits of selection-harvest methods beyond amphibians alone.

Because amphibians often reside on or in the soil, future research might use field experiments to investigate the effects of soil compaction during logging, and the effects of other postharvest site preparation methods (e.g., burning, herbicide application, plowing) as well as their seasonal timing and potential alternatives. As we mentioned, experiments to determine thresholds for the volume and density of retained CWD and the percentage of forest canopy removal will also be critical for understanding mitigation of timber harvest and the limit of sustainable harvest. To fully understand the recovery of amphibian populations, we hope that future studies will link successional changes in vegetation structure to microclimate, food resources, and vital rates. As we have shown, coordinated studies explicitly designed to focus on the 
mechanisms of decline will be most useful in understanding how to reverse declines and conserve amphibian biodiversity.

\section{Acknowledgments}

We thank 33 field assistants for help in constructing fences and enclosures and checking drift fences. We thank Tom Luhring and John Faaborg for comments on this manuscript. This project was supported by the Maine Agriculture and Forest Experiment Station (publication no. 3083), Jeff Briggler and Gus Raeker of the Missouri Department of Conservation and the US Forest Service Savannah River Site, and Frank Thompson of the US Forest Service Central Research Office. Financial support was provided by the National Science Foundation collaborative grants DEB-0239915, DEB-0239943, and DEB-0242874; and by the US Department of Energy through Financial Assistance Award DE-FC09-07SR22506 to the University of Georgia Research Foundation.

\section{References cited}

Adams MJ, Bury RB. 2002. The endemic headwater stream amphibians of the American Northwest: Associations with environmental gradients in a large forested preserve. Global Ecology and Biogeography 11: 169-178.

Armstrong DP. 2005. Integrating the metapopulation and habitat paradigms for understanding broad-scale declines of species. Conservation Biology 19: 1402-1410.

Ash AN. 1995. Effects of clear-cutting on litter parameters in the southern Blue Ridge Mountains. Castanea 60: 89-97.

- 1997. Disappearance and return of plethodontid salamanders to clearcut plots in the southern Blue Ridge Mountains. Conservation Biology 11: 983-989.

Ash AN, Bruce RC. 1994. Impacts of timber harvesting on salamanders. Conservation Biology 8: 300-301.

Biek R, Funk WC, Maxell BA, Mills LS. 2002. What is missing in amphibian decline research: Insights from ecological sensitivity analysis. Conservation Biology 16: 728-734.

Biggs TW, Dunne T, Roberts DA, Matricardi E. 2008. The rate and extent of deforestation in watersheds of the southwestern Amazon basin. Ecological Applications 18: 31-48.

Blomquist SM, Hunter ML Jr. 2009. A multi-scale assessment of habitat selection and movement patterns by northern leopard frogs (Lithobates [Rana] pipiens) in a managed forest. Herpetological Conservation and Biology 4: 142-160.

Bury RB. 1983. Differences in amphibian populations in logged and old-growth redwood forests. Northwest Science 57: 167-178.

Calhoun AJK, deMaynadier P. 2004. Forestry Habitat Management Guidelines for Vernal Pool Wildlife. Metropolitan Conservation Alliance, Wildlife Conservation Society. MCA Technical Paper Series no. 6. (28 September 2009; www.maine.gov/doc/mfs/pubs/pdf/vernal_pool_hmg.pdf)

Chen J, Saunders SC, Crow TR, Naiman RJ, Brosofske KD, Mroz GD, Brookshire BL, Franklin JF. 1999. Microclimate in forest ecosystem and landscape ecology. BioScience 49: 288-297.

Cromer RB, Lanham JD, Hanlin HH. 2002. Herpetofaunal response to gap and skidder-rut wetland creation in a southern bottomland hardwood forest. Forest Science 48: 407-413.

Davic RD, Welsh HH Jr. 2004. On the ecological roles of salamanders. Annual Review of Ecology Evolution and Systematics 35: 405-434.

DeFries R. 2002. Past and future sensitivity of primary production to human modification of the landscape. Geophysical Letters 29: 1132.

DeGraaf RM, Yamasaki M. 2002. Effects of edge contrast on redback salamander distribution in even-aged northern forests. Forest Science 48: 351-363.

deMaynadier PG, Houlahan JE. 2008. Conserving vernal pool amphibians in managed forests. Pages 253-280 in Calhoun AJK, deMaynadier PG, eds. Science and Conservation of Vernal Pools in Northeastern North America. CRC Press.

deMaynadier PG, Hunter ML Jr. 1995. The relationship between forest management and amphibian ecology: A review of the North American literature. Environmental Review 3: 230-261.

Dupuis LA, Smith JNM, Bunnell F. 1995. Relation of terrestrial-breeding amphibian abundance to tree-stand age. Conservation Biology 9: 645-653.

Faaborg J. 2002. Saving Migrant Birds: Developing Strategies for the Future. University of Texas Press.

Gardner TA, Barlow J, Peres CA. 2007. Paradox, presumption, and pitfalls in conservation biology: The importance of habitat change for amphibians and reptiles. Biological Conservation 138: 166-179.

Gibbons JW, Winne CT, Scott DE, Willson JD, Glaudas X, Andrews KM. 2006. Remarkable amphibian biomass and abundance in an isolated wetland: Implications for wetland conservation. Conservation Biology 20: 1457-1465.

Graeter GJ, Rothermel BB, Gibbons JW. 2008. Habitat selection and movement of pond-breeding amphibians in experimentally fragmented pine forests. Journal of Wildlife Management 72: 473-482.

Grialou JA, West SD, Wilkins RN. 2000. The effects of forest clearcut harvesting and thinning on terrestrial salamanders. Journal of Wildlife Management 64: 105-113.

Harper EB. 2007. The role of terrestrial habitat in the population dynamics and conservation of pond-breeding amphibians. $\mathrm{PhD}$ dissertation. University of Missouri, Columbia.

Harper EB, Rittenhouse TAG, Semlitsch RD. 2008. Demographic consequences of terrestrial habitat loss for pool-breeding amphibians: Predicting extinction risks associated with inadequate size of buffer zones. Conservation Biology 22: 1205-1215.

Harpole DN, Haas CA. 1999. Effects of seven silvicultural treatments on terrestrial salamanders. Forest Ecology and Management 114: 349-356.

Herbeck LA, Larsen DR. 1999. Plethodontid salamander response to silvicultural practices in Missouri Ozark forests. Conservation Biology 13: 623-632.

Hocking DJ, Semlitsch RD. 2007. Effects of timber harvest on breeding-site selection by gray treefrogs (Hyla versicolor). Biological Conservation 138: 506-513.

Hocking DJ, Rittenhouse TAG, Rothermel BB, Johnson JR, Conner CA, Harper EB, Semlitsch RD. 2008. Breeding phenology of pond-breeding amphibians in Missouri oak-hickory forests. American Midland Naturalist 160: 41-60.

Hossack BR, Corn PS. 2007. Responses of pond-breeding amphibians to wildfire: Short-term patterns in occupancy and colonization. Ecological Applications 17: 1403-1410.

Hughes JW, Fahey TJ. 1994. Litterfall dynamics and ecosystem recovery during forest development. Forest Ecology and Management 63: 181-198.

Hunter ML Jr., ed. 1999. Maintaining Biodiversity in Forest Ecosystems. Cambridge University Press.

Johnson JR, Knouft JH, Semlitsch RD. 2007. Sex and seasonal differences in the spatial terrestrial distribution of gray treefrog (Hyla versicolor) populations. Biological Conservation 140: 250-258.

Johnson JR, Mahan RD, Semlitsch RD. 2008. Seasonal terrestrial microhabitat use by gray treefrogs (Hyla versicolor) in Missouri oak-hickory forests. Herpetologica 64: 259-269.

Jorgensen BC. 1997. 200 years of amphibian water economy: From Robert Townson to the present. Biological Review 72: 153-237.

Karraker NE, Welsh HH Jr. 2006. Long-term impacts of even-aged timber management on abundance and body condition of terrestrial amphibians in northwestern California. Biological Conservation 131: 132-140.

Keenan RJ, Kimmins JP. 1993. The ecological effects of clear-cutting. Environmental Review 1: 121-144.

Knapp SM, Haas CA, Harpole DN, Kirkpatrick RL. 2003. Initial effects of clearcutting and alternative silvicultural practices on terrestrial salamander abundance. Conservation Biology 17: 752-762.

Kroll AJ. 2009. Sources of uncertainty in stream-associated amphibian ecology and responses to forest management in the Pacific Northwest, USA: A review. Forest Ecology and Management 257: 1188-1199. 
McKenny HC, Keeton WS, Donovan TM. 2006. Effects of structural complexity enhancement on eastern red-backed salamander (Plethodon cinereus) populations in northern hardwood forests. Forest Ecology and Management 230: 186-196.

Moseley KR, Castleberry SB, Ford WM. 2004. Coarse woody debris and pine litter manipulation effects on movement and microhabitat use of Ambystoma talpoideum in a Pinus taeda stand. Forest Ecology and Management 191: 387-396.

Olson DH, Anderson PD, Frissell CA, Welsh HH Jr., Bradford DF. 2007. Biodiversity management approaches for stream-riparian areas: Perspectives for Pacific Northwest headwater forests, microclimates, and amphibians. Forest Ecology and Management 246: 81-107.

Patrick DA, Hunter ML Jr., Calhoun AJK. 2006. Effects of experimental forestry treatments on a Maine amphibian community. Forest Ecology and Management 234: 323-332.

Patrick DA, Harper EB, Hunter ML Jr., Calhoun AJK. 2008. Terrestrial habitat selection and strong density-dependent mortality in recently metamorphosed amphibians. Ecology 89: 2563-2574.

Peterman WE, Crawford JA, Semlitsch RD. 2008. Productivity and significance of headwater streams: Population structure and biomass of the black-bellied salamander (Desmognathus quadramaculatus). Freshwater Biology 53: 347-357.

Petranka JW. 1999. Recovery of salamanders after clearcutting in the southern Appalachians: A critique of Ash's estimates. Conservation Biology 13: 203-205.

Petranka JW, Brannon MP, Hopey ME, Smith CK. 1994. Effects of timber harvesting on low elevation populations of southern Appalachian salamanders. Forest Ecology and Management 67: 135-147.

Pough FH, Smith EM, Rhodes DH, Collazo A. 1987. The abundance of salamanders in forest stands with different histories of disturbance. Forest Ecology and Management 20: 1-9.

Putz FE. 1983. Treefall pits and mounds, buried seeds, and the importance of soil disturbance to pioneer trees on Barro Colorado Island, Panama. Ecology 64: 1069-1074.

Putz FE, Sist P, Fredericksen T, Dykstra D. 2008. Reduced impact logging: Challenges and opportunities. Forest Ecology and Management 256: 1427-1433.

Reichenbach N, Sattler P. 2007. Effects of timbering on Plethodon hubrichti over twelve years. Journal of Herpetology 41: 622-629.

Renken RB, Gram WK, Fantz DK, Richter SC, Miller TJ, Ricke KB, Russell B, Wang X. 2004. Effects of forest management on amphibians and reptiles in Missouri Ozark forests. Conservation Biology 18: 174-188.

Rittenhouse TAG, Semlitsch RD. 2006. Grasslands as movement barriers for a forest-associated salamander: Migration behavior of adult and juvenile salamanders at a distinct habitat edge. Biological Conservation 131: 14-22.

Rittenhouse TAG, Semlitsch RD. 2009. Behavioral response of migrating wood frogs to experimental timber harvest surrounding wetlands. Canadian Journal of Zoology 87: 618-625.

Rittenhouse TAG, Harper EB, Rehard LR, Semlitsch RD. 2008. The role of microhabitats in the desiccation and survival of anurans in recently harvested oak-hickory forest. Copeia 2008: 807-814.

Rittenhouse TAG, Semlitsch RD, Thompson FR III. 2009. Survival costs associated with wood frog breeding migrations: Effects of timber harvest and drought. Ecology 90: 1620-1630.

Ross B, Fredericksen T, Ross E, Hoffman W, Morrison ML, Beyea J, Lester MB, Johnson BN, Fredericksen NJ. 2000. Relative abundance and species richness of herpetofauna in forest stands in Pennsylvania. Forest Science 46: 139-146.

Rothermel BB, Luhring TM. 2005. Burrow availability and desiccation risk of mole salamanders (Ambystoma talpoideum) in harvested versus unharvested forest stands. Journal of Herpetology 39: 619-626.
Seastedt TR, Crossley DA Jr. 1981. Microarthopod response following cable logging and clear-cutting in the southern Appalachians. Ecology 62: 126-135.

Semlitsch RD. 1998. Biological delineation of terrestrial buffer zones for pond-breeding salamanders. Conservation Biology 12: 1113-1119.

Semlitsch RD, Bodie JR. 2003. Biological criteria for buffer zones around wetlands and riparian habitats for amphibians and reptiles. Conservation Biology: 1219-1228.

Semlitsch RD, Ryan TJ, Hamed K, Chatfield M, Drehman B, Pekarek N, Spath M, Watland A. 2007. Salamander abundance along road edges and within abandoned logging roads in Appalachian forests. Conservation Biology 21: 159-167.

Semlitsch RD, Conner CA, Hocking DJ, Rittenhouse TAG, Harper EB. 2008. Effects of timber harvesting on amphibian persistence: Testing the evacuation hypothesis. Ecological Applications 18: 283-289.

Sharitz RR. 2003. Carolina bay wetlands: Unique habitats of the southeastern United States. Wetlands 23: 550-562.

Skelly DK, Halverson MA, Freidenburg LK, Urban MC. 2005. Canopy closure and amphibian diversity in forested wetlands. Wetlands Ecology and Management 13: 261-268.

Stuart SN, Chanson JS, Cox NA, Young BE, Rodrigues ASL, Fischman DL, Waller RW. 2004. Status and trends of amphibian declines and extinctions worldwide. Science 306: 1783-1786.

Taylor BE, Scott DE, Gibbons JW. 2006. Catastrophic reproductive failure, terrestrial survival, and persistence of the marbled salamander. Conservation Biology 20: 792-801.

Todd BD, Andrews KM. 2008. Response of a reptile guild to forest harvesting. Conservation Biology 22: 753-761.

Todd BD, Rothermel BB. 2006. Assessing quality of clearcut habitats for amphibians: Effects on abundances versus vital rates in the southern toad (Bufo terrestris). Biological Conservation 133: 178-185.

Todd BD, Rothermel BB, Reed RN, Luhring TM, Schlatter K, Trenkamp L, Gibbons JW. 2008. Habitat alteration increases invasive fire ant abundance to the detriment of amphibians and reptiles. Biological Invasions 10: 539-546.

Todd BD, Luhring TM, Rothermel BB, Gibbons JW. 2009. Effects of forest removal on amphibian migrations: Implications for habitat and landscape connectivity. Journal of Applied Ecology 46: 554-561.

Ulanova NG. 2000. The effects of windthrow on forests at different spatial scales: A review. Forest Ecology and Management 135: 155-167.

Welsh HH Jr., Droege S. 2001. A case for using plethodontid salamanders for monitoring biodiversity and ecosystem integrity of North American forests. Conservation Biology 15: 558-569.

Young BE, Stuart SN, Chanson JS, Cox NA, Boucher TM. 2004. Disappearing Jewels: Status of New World Amphibians. NatureServe.

Zheng D, Chen J, Song B, Xu M, Sneed P, Jensen R. 2000. Effects of silvicultural treatments on summer forest microclimate in southeastern Missouri Ozarks. Climate Research 15: 45-59.

Raymond D. Semlitsch (semlitschr@missouri.edu), Elizabeth B. Harper, Daniel J. Hocking, and Tracy A. G. Rittenhouse work in the Division of Biological Sciences at the University of Missouri, Columbia. Brian D. Todd, J. Whitfield Gibbons, Gabrielle J. Graeter, and Betsie B. Rothermel are with the University of Georgia, Savannah River Ecology Laboratory, Aiken, South Carolina. Sean M. Blomquist, Aram J. K. Calhoun, Malcolm L. Hunter Jr., and David A. Patrick work in the Department of Wildlife Ecology at the University of Maine, Orono. James P. Gibbs is with the State University of New York College of Environmental Science and Forestry, Syracuse. 